\title{
Effects of a deep-rooted crop and soil amended with charcoal on spatial and temporal runoff patterns in a degrading tropical highland watershed
}

\author{
Haimanote K. Bayabil ${ }^{1}$, Tigist Y. Tebebu ${ }^{1}$, Cathelijne R. Stoof ${ }^{1,2}$, and Tammo S. Steenhuis ${ }^{1,3}$ \\ ${ }^{1}$ Department of Biological and Environmental Engineering, Cornell University, Ithaca, New York, USA \\ ${ }^{2}$ Soil Geography and Landscape Group, Wageningen University, the Netherlands \\ ${ }^{3}$ School of Civil and Water Resources Engineering, Bahir Dar University, Bahir Dar, Ethiopia
}

Correspondence to: Tammo S. Steenhuis (tss1@ cornell.edu)

Received: 23 February 2015 - Published in Hydrol. Earth Syst. Sci. Discuss.: 30 April 2015

Revised: 27 December 2015 - Accepted: 18 January 2016 - Published: 24 February 2016

\begin{abstract}
Placement and hence performance of many soil and water conservation structures in tropical highlands has proven to be challenging due to uncertainty of the actual location of runoff-generating areas in the landscape. This is the case especially in the (sub-)humid areas of the Ethiopian highlands, resulting in limited success of such conservation measures. To improve understanding of the effect of land use on spatial and temporal runoff patterns in the Ethiopian highlands, we monitored runoff volumes from 24 runoff plots constructed in the 113 ha Anjeni watershed, where historical data of rainfall and stream discharge were available. In addition, we assessed the effectiveness of charcoal amendment of the soil and crop rooting depth in reducing runoff, and we compared the effect of lupine (a deep-rooted crop) to that of barley. We also measured daily rainfall, surface runoff, and root zone moisture contents during the monsoon seasons of 2012 and 2013 (with all plots being tilled in 2012, but only barley plots tilled in 2013). In addition, we analyzed longterm surface runoff from four plots, and outlet discharge data from the research site (1989-1993) were analyzed and compared with our observations. Results showed that the degrees of soil degradation and soil disturbance (tillage) were significant factors affecting plot-scale runoff responses. As expected, runoff was greater from more degraded soils. Overall, under the commonly applied lupine cropping practice, runoff was higher than under the commonly applied barley cropping practice. In particular, considerable difference was observed during smaller rainfall events (approximately $<20 \mathrm{~mm}$ ) in 2013, when lupine plots (non-tilled) had greater runoff than
\end{abstract}

barley plots (tilled). Charcoal tended to decrease runoff, but results were not significant.

\section{Introduction}

Performance of many soil and water conservation structures in the tropical highlands has proven to be challenging due to uncertainty of their optimal placement. Ideally, the location of conservation structures should be directly related to where runoff is generated in the landscape. Evaluating the effectiveness of landscape modifications is especially timely in the Ethiopian highlands where the Ethiopian government is implementing land management practices to both increase rainwater productivity in the degrading landscape and increase the life of hydroelectric power plants such as the Grand Ethiopian Renaissance Dam on the Blue Nile near Sudan (Chen and Swain, 2014; Dagnew et al., 2015). The ultimate goal of these actions is to increase prosperity and ensure food security for the rapidly increasing population (Hurni, 1988; Nyssen et al., 2009). Most areas in the Ethiopian highlands receive high amounts of annual precipitation, aiding soil leaching and promoting land degradation; however, water scarcity is common for 8-9 months every year (Amsalu and Graaff, 2006; Bewket and Sterk, 2005; Biazin et al., 2011; Hugo et al., 2002). Rainfall distribution is variable not only spatially, but also temporally (Biazin et al., 2011; Bitew et al., 2009; McHugh et al., 2007). To counteract this problem of periodic water scarcity, soil and water conservation 
practices are ubiquitous in the Ethiopian highlands. However, surprisingly, most non-traditional soil and water conservation practices are ineffective because their placement neither addresses drivers of runoff nor considers spatial and temporal variation of runoff in a landscape.

Planning of effective soil and water management measures requires knowledge of dominant runoff-generating mechanisms and their controlling factors (e.g., land use, topography) (Orchard et al., 2013). There are two mechanisms of surface runoff generation: (1) Hortonian overland flow or infiltration excess surface runoff that occurs when rainfall intensity exceeds the infiltration capacity of the soil, and (2) saturation excess surface runoff that occurs when the (perched) water table rises, saturating the whole soil profile. However, there is still a lack of agreement regarding the nature of the runoff initiation mechanisms and their controlling factors in the Ethiopian highlands. Previous studies highlighted saturation excess as the dominant runoff mechanism (Bayabil et al., 2010; Steenhuis et al., 2009; Tilahun et al., 2013, 2014). A field study by Bayabil et al. (2010) found that in the Maybar watershed, with highly conductive soils, saturation excess runoff was mainly driven by topography, with water channeling through the hillsides as interflow, saturating the lower-lying fields. This is in line with findings from the Debra Mawi watershed in the northern Ethiopian highlands, where saturated lower-lying fields contributed most of the surface runoff (Tilahun et al., 2013). This strong evidence for saturation excess runoff being the driver of overland flow in the Ethiopian highlands is in contrast to findings from Bewket and Sterk (2005) and Taddese (2001). A study by Bewket and Sterk (2005) in the Chemoga watershed located in the Blue Nile basin, like the Anjeni and Debre Mawi watersheds, found that infiltration excess runoff mechanism was dominant mainly based on analysis of the hydrograph at the outlet focusing on land use change. Land use is important because it affects soil infiltration capacity. For example, several studies reported that land use change from natural vegetation to agricultural lands increased overland flow during the rainy monsoon phase and reduced baseflow during the dry phase in this region (Bewket and Sterk, 2005; Feoli et al., 2002; Taddese, 2001; Zeleke, 2000). In other countries as well, clearing of forests resulted in decreased infiltration rates and lower percolation to the sub-soils (Hanson et al., 2004; Mendoza and Steenhuis, 2002; Nyberg et al., 2012; Shougrakpam et al., 2010). Identification of the dominant runoff mechanism in relation to not only topography but also land use in the Ethiopian highlands is therefore essential for the development of effective soil and water conservation methods in this region.

On degraded fields with poor soil infiltration capacity, management practices should aim at improving infiltration rates. This can be done by restoring the soil macropore network by improving soil organic carbon pools, or by disturbing the soil profile either physically (tillage) or biologically (using deep-rooted crops). Deep-rooted crops can penetrate through the soil profile and thereby increase soil conductivity (Angers and Caron, 1998; Cresswell and Kirkegaard, 1995; Lesturgez et al., 2004; Meek et al., 1992). Moreover, upon decomposition of these roots, channels and biopores are created that could provide a network of macropores with considerable vertical and lateral conductivity (Yunusa and Newton, 2003).

Another solution for improving soil physical and hydraulic properties is by increasing the organic carbon pool through the addition of biochar or charcoal (Abel et al., 2013; Asai et al., 2009; Bayabil et al., 2015; Glaser et al., 2002; Kameyama et al., 2010; Karhu et al., 2011; Laird et al., 2010). Biochar and charcoal incorporation have been reported to improve soil bulk density (Abel et al., 2013; Laird et al., 2010), porosity (Abel et al., 2013; Atkinson et al., 2010), and hydraulic conductivity (Asai et al., 2009). Although both biochar and charcoal soil amendments can be effective in improving soil hydraulic properties, Bayabil et al. (2015) argued that charcoal is a more viable solution for rural Africa because it is widely produced in most rural areas of Africa (Lehmann et al., 2006) and is therefore more accessible to smallholder farmers than biochar. The analysis above shows that deeprooted crops and additions of charcoal could ameliorate soil and water losses in a degrading landscape. However, field research on the effectiveness of these two management practices in a tropical highland setting with monsoon rainfalls, to our knowledge, does not exist.

The objective of this study was, therefore, to investigate spatial and temporal rainfall-runoff relationships in the Ethiopian highlands by investigating the effects of soil degradation status and landscape position. For this, soil degradation status was experimentally changed by adding biochar and growing a deep-rooted lupine crop.

The research was carried out in the Anjeni watershed in the Ethiopian highlands in 2012 and 2013. Twenty-four runoff plots were established along three transects going upslope in sets of three in each landscape position. Each set of three plots had one plot in which lupine was planted and two plots with barley - of which one was amended with charcoal.

\section{Materials and methods}

\subsection{Study site}

The Anjeni watershed is situated in the northwestern part of Ethiopia (Fig. 1), and was selected because of the availability of historical discharge records at the outlet and from runoff plots inside the watershed. The watershed has a drainage area of $113 \mathrm{ha}$ and is one of the experimental watersheds established under the Soil Conservation and Research Program (SCRP) of the Ministry of Agriculture of Ethiopia in collaboration with the Swiss Agency for Development and Cooperation (SDC; Hurni et al., 2005). Its gauging station is located at $10^{\circ} 40^{\prime} \mathrm{N}, 37^{\circ} 31^{\prime} \mathrm{E}$. 

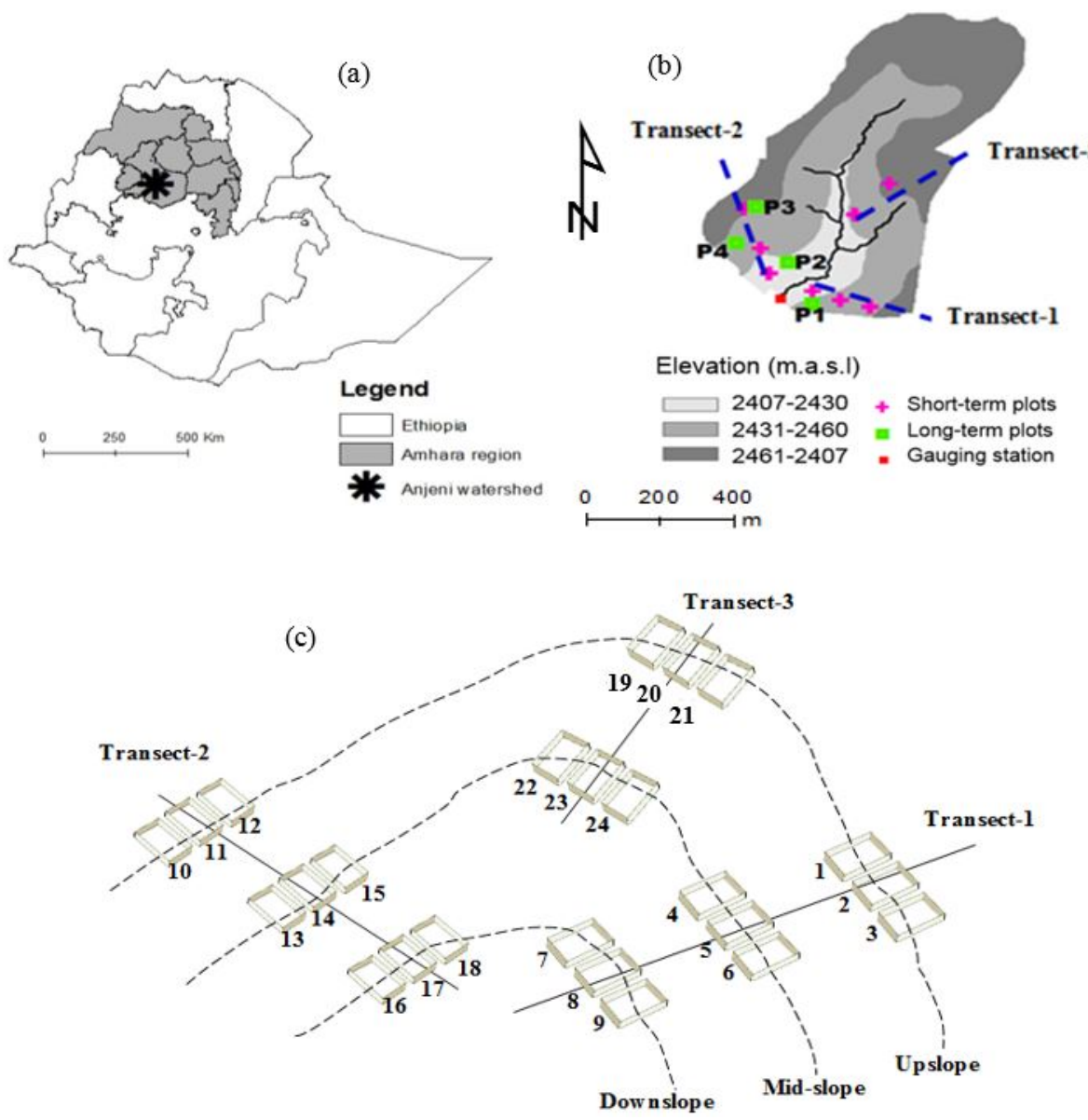

Figure 1. Location of the Anjeni watershed in the Amhara region in Ethiopia (a), with the location of downslope transects and runoff plots indicated in (b) and (c) (not to scale). Dashed lines in (c) are elevation contours. Three treatments were applied: barley without soil amendment (control) was grown on plots 2, 4, 7, 12, 15, 18, 21, and 23; barley with charcoal amendment was grown on plots 1, 6, 8, 11, 13, 17,20 , and 22; and lupine without soil amendment was grown on plots $3,5,9,10,14,16,19$, and 24. Soil and spatial attributes of plots are presented in Table 1.

The watershed has a unimodal rainy season that lasts from mid-May to mid-October, with a mean annual rainfall of $1690 \mathrm{~mm} \mathrm{yr}^{-1}$. The topography of Anjeni is typical of Tertiary volcanic landscapes: it has been deeply incised by streams, resulting in the current diversity of landforms (SCRP, 2000) with elevation between 2407 and $2507 \mathrm{~m}$ a.s.1. (Herweg and Ludi, 1999). The soils of Anjeni have been developed from the basaltic Trapp series of Tertiary volcanic eruptions and are similar to most parts of central Ethiopia, with the dominant soils being Alisols (41.5 ha), Nitisols (23.8 ha), Cambisols (18.9 ha) and Regosols (10 ha) covering more than $80 \%$ of the watershed (Fig. S1 in the Supplement; SCRP, 2000; Zeleke, 2000). The deep Alisols cover the bottom part of the watershed; moderately deep Nitisols cover the mid-transitional, gently sloping parts of the watershed, while the shallow Regosols and Leptosols cover the high, steepest part of the watershed (Zeleke, 2000). Fields are intensively cultivated for crop production and a large proportion of the watershed is degraded (SCRP, 2000). In 1986, graded fanyajии structures were installed for soil and water conservation, resulting in terraces across the landscape (SCRP, 2000).

\subsection{Experimental setup}

We studied the effect of land use and soil management on runoff patterns using 24 runoff plots installed across the watershed, accounting for spatial variability in soil degradation status and slope position (Table 1, Fig. 1). We also assessed effects of charcoal amendment and crop rooting depth along three transect locations. The 24 plots were positioned in groups of three along three transects perpendicular to the slope (Fig. 2). Soil degradation varied between transects: Transects 1 and 2 are located in the southeastern and southwestern parts of the watershed (Fig. 1b), and have deep soils, while Transect 3, located between Transects 1 and 2, is characterized by shallow and degraded soils. Transects 1 and 3 are steep (with slopes approximately 14.5 and $15.6 \%$, re- 


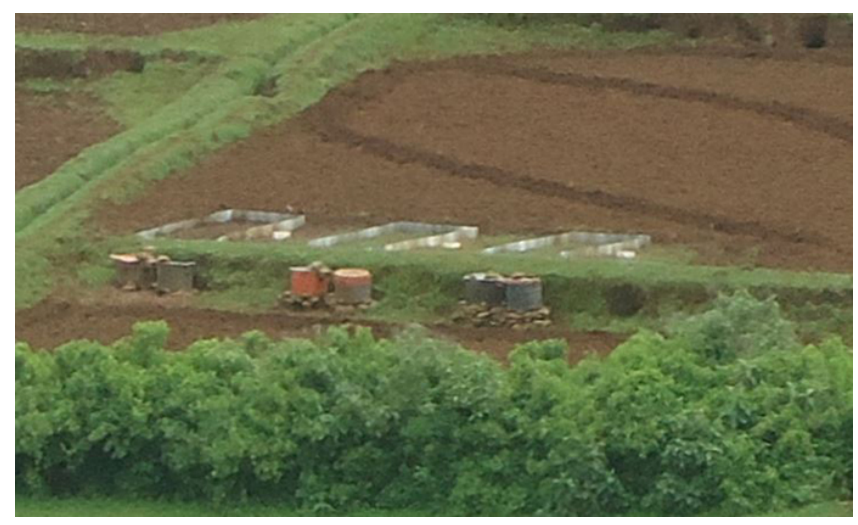

Figure 2. Groups of three runoff plots setup in the downslope position along Transect 2. Water storage tanks are positioned below the plots, on the downslope side of the terrace edge. Dark brown lines above runoff plots are traditional conservation practices (drainage ditches) constructed by farmers to channel out excess water from fields.

spectively), while Transect 2 has a moderate slope (11.8\%). Effects of landscape position were assessed by placing plots at different slope positions: at downslope, mid-slope, and upslope positions along Transects 1 and 2; and in the two upper positions along Transect 3 (Fig. 1c). A randomized block experimental design type using transects as blocking factors was used during installation of plots, with the effect of charcoal and a deep-rooting crop assessed in every landscape position.

At the start of the 2012 growing season (June), all plots were plowed and, in each landscape position (Fig. 1), two plots were seeded with barley. Effects of charcoal amendment were assessed by amending one of the barley plots with charcoal during plowing, the non-amended barley plot serving as a control treatment. Effects of crop rooting depth were assessed by seeding the third plot at each transect location with the deep-rooted lupine (Lupineus albus L.) crop, with the non-amended barley plot again serving as a control treatment. Barley and lupine crops were assigned randomly to plots, and the same crop was maintained on each plot for 2 years (2012 and 2013). These crops were chosen as they are widely grown throughout the Ethiopian highlands. Farmers grow lupine as intercrop with cereals (e.g., barley and wheat) or as the sole crop on marginal lands without additional farm inputs. Barley has a fibrous root system, while lupine has a deep-rooted system and is widely grown on marginal lands for its leguminous nature. Because of their contrasting root architecture, lupine and barley are expected to have contrasting effects on soil hydraulic properties.

\subsection{Agronomic practices on plots}

Barley, one of the predominantly grown crops in the watershed (SCRP, 2000), was grown following local farmers' cultural practices, and thus barley plots were tilled in both 2012 and 2013. While lupine seed beds are typically not tilled, tillage was done in 2012 because the plots were originally designated to be sown with alfalfa, another deep-rooted crop though one that is always tilled. When the alfalfa did not establish itself successfully, lupine was sown on the tilled soil shortly after. The next growing season, in 2013, only barley plots were tilled and seeded, while lupine seeds were seeded on untilled plots (the more common practice in the area). Also in line with farmer practices, all barley plots were fertilized with $100 \mathrm{~kg} \mathrm{ha}^{-1}$ di-ammonium phosphate (DAP; $46 \%$ nitrogen, $23 \%$ phosphorous, and $21 \%$ potassium) during seeding, and $100 \mathrm{~kg} \mathrm{ha}^{-1}$ of urea (100\% nitrogen) 1 month after sowing. Lupine plots were not fertilized. Both fertilization and tillage are different for lupine and barley treatments during the 2-year study period (2012 and 2013). To distinguish crop effects (barley and lupine crops grown under common practices) from tillage effects, we therefore analyzed data from the 2-year study separately.

On charcoal-amended barley plots, charcoal was applied at a fixed rate of 12 ton/ha during tillage in 2012 and 2013. Charcoal (prepared from Eucalyptus camaladulensis biomass in a way similar to that described by Bayabil et al., 2015) was manually crushed to obtain a relatively uniform particle size ( $2 \mathrm{~mm}$ diameter) and then manually mixed with the top $20 \mathrm{~cm}$ of the soil.

\subsection{Plot installation and data collection}

While crop and charcoal treatments were applied to $9 \mathrm{~m}^{2}$ ( $3 \mathrm{~m}$ wide, $3 \mathrm{~m}$ long) areas, runoff was only measured on $4.5 \mathrm{~m}^{2}$ plots ( $1.5 \mathrm{~m}$ wide, $3 \mathrm{~m}$ long) inside these areas, to allow for auxiliary measurements (e.g., soil moisture content) to be taken adjacent to instead of inside the runoff plots and thereby avoid trampling and soil disturbance inside the plots. For this, runoff plot boundaries were installed $0.75 \mathrm{~m}$ inside the seeded area from both sides. As illustrated in Fig. 2, all runoff plots were constructed at the level bottom ends of terraces. The plot boundaries consisted of $50 \mathrm{~cm}$ high metal sheets of which $25 \mathrm{~cm}$ were below ground and $25 \mathrm{~cm}$ were above ground, and the lower plot boundaries were reinforced with concrete. A $5 \mathrm{~cm}$ diameter PVC pipe carried surface runoff into primary collection tanks ( $76 \mathrm{~L}$ volume). When the primary tanks were full, excess water flowed through divisor slots directing one-tenth $(10 \%)$ of the excess flow into secondary tanks ( $76 \mathrm{~L}$ volume). The tanks were made from barrels cut in half and were covered on the top to minimize evaporation and prevent rainfall entry.

All plots were monitored manually for runoff on a daily basis during the monsoon season (from 29 June to 4 October 2012 and from 25 June to 8 October 2013). When runoff occurred, the depth of water in the two tanks was measured and then the water was drained out through valves fitted at the bottom of the tanks. Daily rainfall totals were measured using a manual rain gauge installed at the weather station situated in the watershed (see Fig. 1b, "Weather station"). In 
Table 1. Spatial attributes and soil properties of plots.

\begin{tabular}{lllllllllll}
\hline Transect & Position & Plots & $\begin{array}{l}\text { Elevation } \\
(\mathrm{m} \text { a.s.1. })\end{array}$ & $\begin{array}{l}\text { Slope } \\
(\%)\end{array}$ & Sand & $\begin{array}{l}\text { Silt } \\
(\%)\end{array}$ & Clay & $\mathrm{OM}^{1}$ & $\begin{array}{l}\mathrm{BD}^{2} \\
\left(\mathrm{~g} \mathrm{~cm}^{-3}\right)\end{array}$ & $\begin{array}{l}\mathrm{D}^{3} \\
(\mathrm{~m})\end{array}$ \\
\hline \multirow{2}{*}{ One } & Upslope & $1,2,3$ & 2438 & 3.0 & 24.8 & 35.4 & 39.8 & 2.2 & 1.1 & 1.15 \\
& Mid-slope & $4,5,6$ & 2431 & 2.5 & 31.7 & 28.0 & 40.3 & 2.1 & 1.1 & 1.22 \\
& Downslope & $7,8,9$ & 2411 & 1.5 & 23.6 & 36.7 & 39.6 & 2.2 & 1.1 & $>1.3$ \\
\hline \multirow{2}{*}{ Two } & Upslope & $10,11,12$ & 2461 & 2.5 & 23.8 & 32.2 & 44.0 & 2.1 & 1.1 & 0.84 \\
& Mid-slope & $13,14,15$ & 2426 & 2.0 & 17.8 & 39.0 & 43.2 & 2.4 & 1.2 & 1.09 \\
& Downslope & $16,17,18$ & 2415 & 1.0 & 24.7 & 36.3 & 39.0 & 2.4 & 1.3 & $>1.3$ \\
\hline \multirow{2}{*}{ Three } & Upslope & $19,20,21$ & 2455 & 3.0 & 21.0 & 37.7 & 41.4 & 1.3 & 1.4 & 0.33 \\
& Mid-slope & $22,23,24$ & 2438 & 2.0 & 30.6 & 37.4 & 32.0 & 1.4 & 1.3 & 0.72 \\
\hline
\end{tabular}

${ }^{1}$ OM: organic matter; ${ }^{2}$ BD: bulk density; and ${ }^{3}$ D: soil depth.

addition, during the 2013 growing period, soil moisture content, $\theta\left(\mathrm{g} \mathrm{g}^{-1}\right)$, was measured gravimetrically by taking bulk soil samples from the top $20 \mathrm{~cm}$ depth at 10 -day intervals. To prevent disturbance, samples were taken inside the seeded area but just outside each runoff plot.

\subsection{Long-term plot runoff and river discharge data}

In addition to runoff data from the 24 newly installed plots, we obtained long-term data from the Amhara Regional Agricultural Research Institute (ARARI). The data consist of runoff from four long-term $3 \mathrm{~m}^{2}$ plots ( $3 \mathrm{~m}$ length, $1 \mathrm{~m}$ width; Fig. 1b, "Permanent plots") and discharge at the outlet of the watershed (Fig. 1b, "Gauging station"). To place our newly installed plot-scale runoff observations into a broader and longer-term context, we compared our data with historical plot-scale runoff data available in the watershed for the years 1989 through 1993. These data were measured on the four $3 \mathrm{~m}^{2}$ plots that had slopes of $12,16,22$, and $28 \%$. The $16 \%$ sloped plot was on grassland, while the other three plots were cultivated with food crops (e.g., barley and wheat; SCRP, 2000). Discharge was measured continuously since 1984 (2 years before the installation of the fanya juu conservation structures) as part of the ongoing hydrological and erosion monitoring activities (SCRP, 2000), and we used discharge data for the 2012 and 2013 monsoon seasons to compare our plot-scale observations with watershed-scale patterns. Rainfall data obtained from the watershed (Fig. 1b, "Weather station") were available for the same period.

\subsection{Data quality control and aggregation}

To make sure that peaks of daily rainfall and runoff coincided, we checked all daily data visually and by calculating the daily runoff coefficients ( $R_{\text {coef }}$ ) using Eq. (1):

$R_{\text {coef }}=\frac{\text { runoff }}{\text { rainfall }}$ where runoff is daily runoff $\left(\mathrm{mm} \mathrm{day}^{-1}\right)$ and rainfall is daily rainfall amount $(\mathrm{mm})$.

Plot-scale rainfall-runoff data (Figs. S2-S4 in the Supplement) showed that there were 214 events (spread over 11 days in 2012 and 32 days in 2013) out of 5232 events in total (i.e., $4.1 \%$ of the total) where daily runoff was greater than the rainfall amount recorded on the same day (i.e., $R_{\text {coef }}>1$ ). In some cases, large rainfall events were visible that did not produce runoff on the same day, but for which peak runoff appeared on the following day. In other cases, there was more runoff than rainfall without delays (see spikes of blue, green, and red lines in Figs. S2-S4 in the Supplement). Runoff in excess of rainfall can be caused by rainfall and runoff measurement periods that do not coincide. Here, rainfall was measured at 08:00 every day. The first of the 24 runoff plots was also measured at 08:00, but emptying the barrels and scooping out the sediment is time consuming, causing the last plot to be emptied around noon. Rainfall and runoff periods therefore did not exactly coincide, which likely caused problems on days on which rainfall occurred between 08:00 and 12:00 (noon). Other potential causes of runoff exceeding rainfall are high spatial variation in rainfall that is not picked up by our single rain gauge, and interflow from outside the plot entering the plot during large rainstorms.

To reduce the impact of delayed peak runoff, we therefore decided to aggregate rainfall and runoff data over a 3-day period, resolving most of the high runoff coefficients. However, 47 events ( $2.6 \%$ of total) observed on the 24 plots and recorded on 11 observation days spread over the 2-year study period were left with $R_{\text {coef }}>1$ (Fig. S5 in the Supplement). Further data aggregation, even on a weekly interval, did not resolve the issue. One of the options to deal with such outlier data points would be to exclude observations from data analysis. However, to avoid bias between treatments and spatial locations, all observations from those 11 days would need to be discarded for all (24) plots, which would result in discarding 264 observations. Losing this many observations (14.9\% of a total of 1777 3-day observations) would considerably re- 
Table 2. Summary of total runoff during the year ("Total runoff"), average 3-day runoff in mm ("Mean runoff") and standard error (SE*) in $\mathrm{mm}$ average of the plots in the transect for 2012 and 2013. The annual precipitation in 2012 and 2013 was 1036 and $1528 \mathrm{~mm}$, respectively.

\begin{tabular}{llllllll}
\hline Plot & Rainfall/runoff $(\mathrm{mm})$ & \multicolumn{3}{c}{2012} & \multicolumn{3}{c}{2013} \\
& & \multicolumn{3}{c}{ Transect } & \multicolumn{3}{c}{ Transect } \\
\cline { 3 - 9 } & & 1 & 2 & 3 & 1 & 2 & 3 \\
\hline Control & Total runoff & 438 & 484 & 598 & 300 & 367 & 482 \\
& Mean runoff & 13 & 15 & 18 & 9 & 10 & 14 \\
& SE & 2.8 & 2.5 & 3 & 1.7 & 2.7 & 2.5 \\
\hline Charcoal & Total runoff & 365 & 468 & 513 & 282 & 365 & 397 \\
& Mean runoff & 11 & 14 & 15 & 8 & 10 & 11 \\
& SE & 2.2 & 2.5 & 2.6 & 2.1 & 3 & 2.3 \\
\hline Lupine & Total runoff & 509 & 495 & 583 & 732 & 670 & 747 \\
& Mean runoff & 16 & 15 & 18 & 21 & 19 & 21 \\
& SE & 2.8 & 2.4 & 2.5 & 3.3 & 3.4 & 3.1 \\
\hline Rainfall & Total rainfall & & 1036 & & & 1528 \\
& Mean rainfall & & 32 & & & 43 & \\
& SE & & 0.5 & & & 0.8 & \\
\hline
\end{tabular}

* SE: standard error of the mean.

duce the power of our analysis. Thus, to achieve a balance between the number of runoff events remaining for analysis and the objective of analyzing large runoff events, the remaining high runoff events $\left(R_{\text {coef }}>1\right)$ after data aggregation on 3day intervals were therefore assigned a maximum value that equals the 3-day rainfall amount - resulting in a runoff coefficient of 1 . As such, adjusted 3-day aggregate runoff data were used for all statistical data analyses in this paper.

In addition to this analysis of runoff coefficients, to assess the differences in soil water storage between plots, the SCS curve number was fitted to 3-day rainfall and 3-day adjusted runoff data for each treatment type and cropping year using Eq. (2). The SCS equation was effectively used in predicting rainfall-runoff relationships in the Ethiopian highlands (Tilahun, 2012) and for different regions in the USA and Australia (Steenhuis et al., 1995). The SCS curve number equation (Rallison, 1980) is represented as

$Q=\frac{\left(P_{e}-0.2 S\right)^{2}}{\left(P_{e}+0.8 S\right)}$,

where $Q$ is 3-day runoff (mm), $P_{e}$ is 3-day rainfall (mm), and $S(\mathrm{~mm})$ is potential maximum soil storage.

\subsection{Statistical analysis}

Data analysis aimed at detecting differences in runoff response between land uses and spatial locations (transects and elevation ranges) during the 2-year study period. Statistical data analysis was performed using $\mathrm{R}$ ( $\mathrm{R}$ Development Core Team, 2014). To determine the effect of charcoal amendment and deep-rooted lupine as well as spatial location with different soil degradation levels (transects) and slope position, a linear mixed effect model was fitted using the nlme package in R. In this model, crop type, slope position, and transect were used as fixed factors, and individual plots as random factors. For fixed factors with significant effects, post hoc mean comparison tests were performed using the lsmeans package in $\mathrm{R}$ to identify group pairs with significant difference.

\section{Results and discussion}

\subsection{Plot-scale rainfall-runoff response and effect of charcoal amendment and deep-rooted lupine}

The adjusted runoff depths during the monsoon seasons of 2012 and 2013 are shown in Fig. 3 for all eight groups of plots along the three transects. In 2013, runoff response from lupine plots was considerably greater than barley plots, while in 2012, runoff tended to be more or less similar for all treatments. In addition, a summary of observed rainfall data recorded is presented in Table 2. Average monthly rainfall in 2012 was similar to the 5-year average (based on 1989-1993 observations; Fig. S6 in the Supplement), while in 2013 it exceeded the 5-year average.

As discussed in the "Methods" section, runoff exceeding rainfall (i.e., $R_{\text {coef }}>1$ ), as shown in Figs. S2-S4 and S5 in the Supplement, is not expected and worrisome. We therefore checked historical long-term data (1989-1993) from four permanent plots ( $3 \mathrm{~m}$ length, $1 \mathrm{~m}$ width) measured by the well-trained technicians at the experimental station, and found the same "problem" that in many cases there was more runoff than rainfall (Fig. 4a). This indicates that our daily observations with $R_{\text {coef }}>1$ (Fig. $4 \mathrm{~b}$ ) are real and not caused 
by measurement errors. This phenomenon of runoff exceeding rainfall has not been reported often for temperate climates, and it is therefore likely that rainfall in monsoon climates is more variable over short distances than rains in temperate climates. Studies found that rainfall in the Ethiopian highlands significantly varies in space (Bewket and Conway, 2007; Bitew et al., 2009). Bitew et al. (2009) observed an up to $424 \%$ coefficient of variation of daily rainfall between rain gauges. These authors further noted that in areas with complex topography (like the Anjeni watershed), extrapolation of point rainfall observations to larger scales could be less accurate.

\subsection{Plot runoff and outlet discharge}

All plots on degraded soils along Transect 3 produced significantly greater runoff than plots along the other two transects with relatively deeper soils (Fig. S7 in the Supplement). While we expected slope position to affect runoff, results from the linear mixed effects model showed that plot-scale runoff responses between slope positions were not significant. Because of this, 2012 and 2013 runoff responses of barley (both control and charcoal amended) and deep-rooted lupine were grouped by transect and then compared. Statistical test results showed that, for all transects, lupine plots produced significantly more runoff than both the control and charcoal-amended barley plots. Charcoal amendment, on the other hand, caused no significant effects (Fig. 5). The cumulative runoff for the lupine plots followed the cumulative runoff for the outlet more than the barley plots, particularly in 2013 (Fig. 6).

Comparison of plot-scale cumulative runoff (colored lines, Fig. 6) and cumulative river discharge observed at the watershed outlet (black line, Fig. 6) with cumulative rainfall indicated that approximately $100 \mathrm{~mm}$ of cumulative rainfall was needed before runoff was initiated from all plots. In general, during the start of the monsoon season (until $500 \mathrm{~mm}$ cumulative rainfall in Fig. 6), plot-scale runoff response generally exceeded watershed-scale discharge response. In agreement with this, Mutema et al. (2015), a study in South Africa, observed a significant reduction in unit runoff as plot size increased from micro-plots $\left(1 \mathrm{~m}^{2}\right)$ to plots $\left(10 \mathrm{~m}^{2}\right)$ and subsequently to mico-catchments $\left(0.23 \mathrm{~km}^{2}\right)$. Similarly, van de Giesen et al. (2011) reported that runoff decreased with increases in plot size. Nevertheless, as the rainy season progressed, starting from the middle of August and at approximately $500 \mathrm{~mm}$ cumulative rainfall, watershed-scale discharge started to exceed plot-scale runoff depths (with the exception of the lupine plots in 2013; see below). The difference between plot-scale runoff and outlet discharge during the onset of the monsoon season indicates that detention storage at a watershed scale occurs, while the difference between the plot and watershed scale later in the monsoon season is caused by baseflow at the watershed outlet. This is consistent with previous observations by Tilahun et al. $(2013,2014)$ and

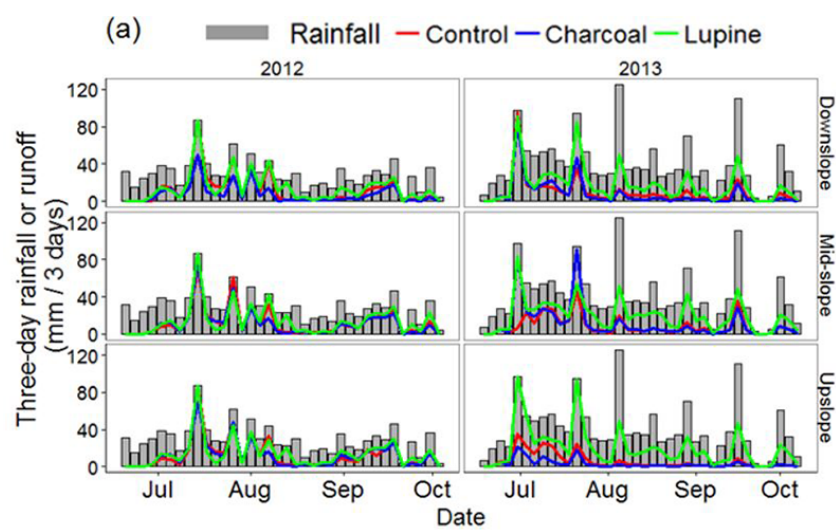

(b)

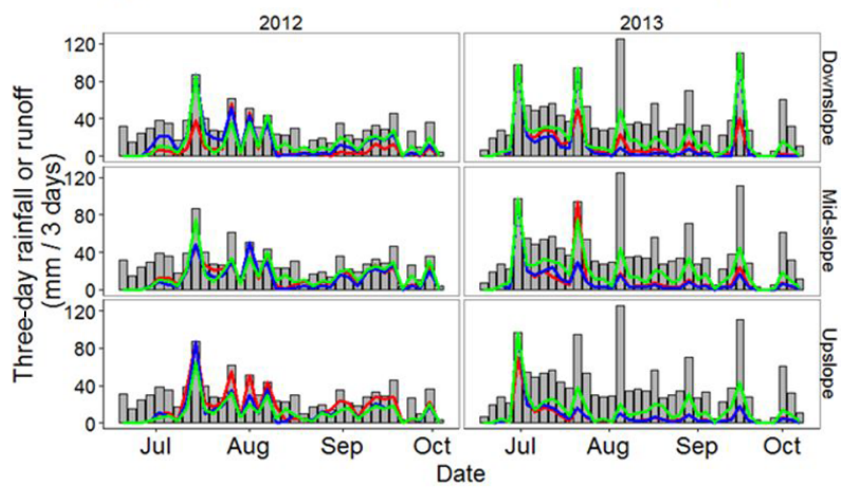

(c)

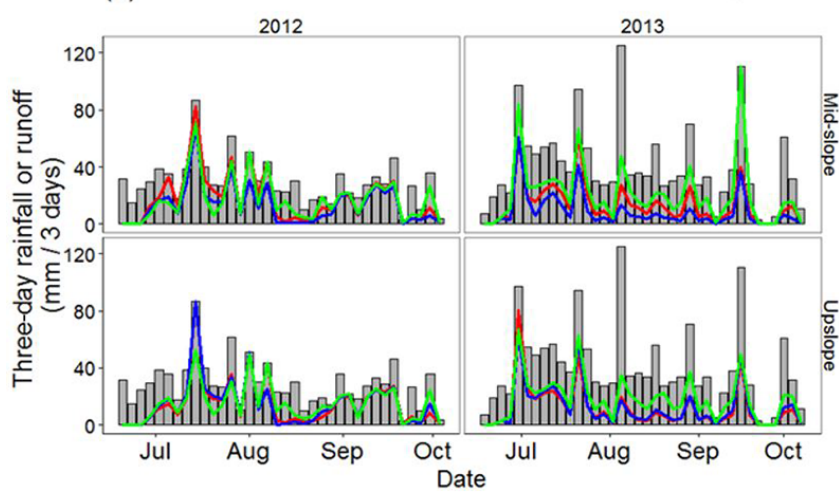

Figure 3. Three-day rainfall and adjusted 3-day runoff depths (aggregated over 3 days) from individual plots in different slope positions along Transect 1 (a), Transect 2 (b), and Transect 3 (c).

Bayabil et al. (2010), who observed that initially, the runoff from the hillsides infiltrates to a lower slope position as interflow, while later in the season these bottom lands start to contribute both subsurface flow and surface runoff.

A considerable difference in the runoff response of barley and lupine plots was observed between the monsoon seasons of 2012 and 2013. In 2012, runoff tended to be more or less similar for all treatments, whereas in 2013 runoff from barley and lupine plots began to deviate after approx- 
(a)

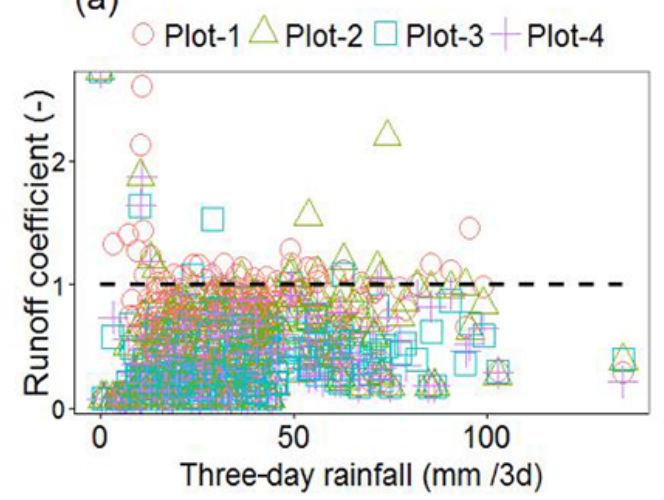

(b)

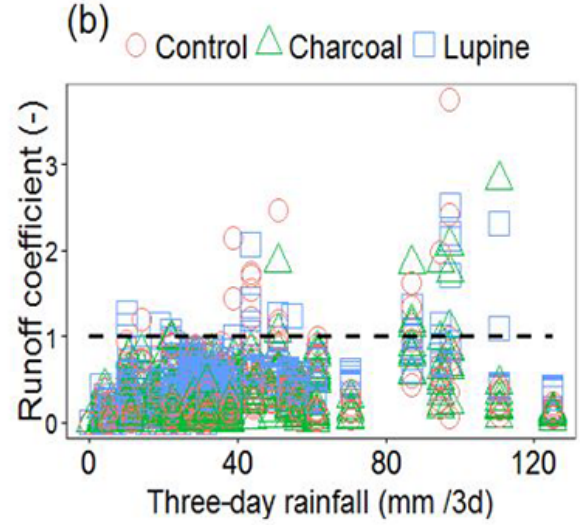

Figure 4. Runoff coefficients computed from observations from long-term monitoring plots ( $3 \mathrm{~m}$ length, $1 \mathrm{~m}$ width) (a) and plots in 2012 and 2013 (b). The black-dashed horizontal line represents $R_{\text {coef }}=1$.

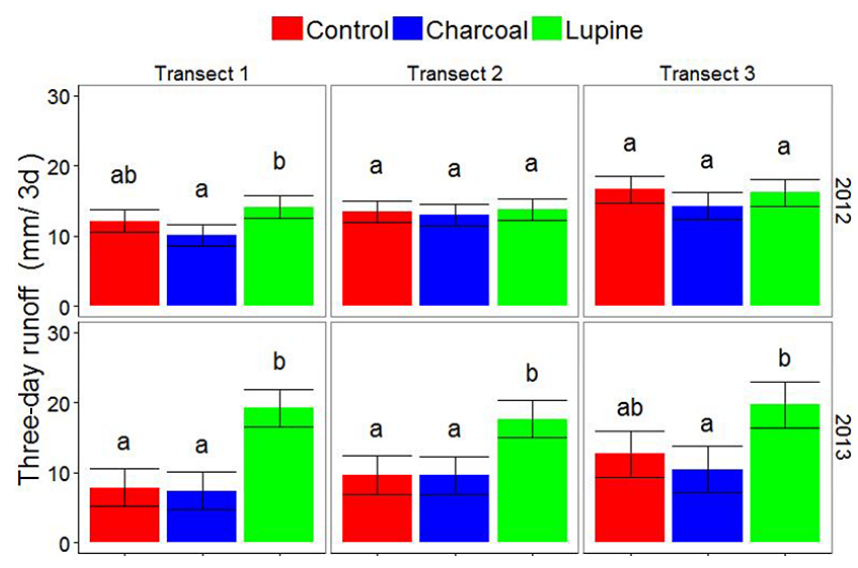

Figure 5. Effect of charcoal amendment and deep-rooted lupine crop on plot-scale runoff (3-day total) for each transect and year. Treatments not sharing the same letter within an individual transect for a given year are significantly different at $p<0.05$.

imately $250 \mathrm{~mm}$ cumulative rainfall (Fig. 6). In agreement with this, a closer look at the plots (Fig. 3) clearly shows that for most of the high rainfall amounts, there is little difference in runoff response between the barley and lupine plots. Only for smaller rain events (approximately $<20 \mathrm{~mm}$ ) and during the start of the 2013 rainy season (around 1 July) did runoff from lupine plots exceed that of barley plots. It is interesting that this is the case for all three transects in 2013 but does not occur in 2012. The only management difference between these 2 years is that lupine was tilled in 2012 but not in 2013 . This implies that tillage resulted in relatively greater soil water storage for lupine plots, and that the difference in rainfallrunoff response between these crop treatments in 2013 may be ascribed to the fact that barley plots were tilled and lupine plots were not. Soil water storage estimated by fitting the SCS-CN equation (Rallison, 1980) confirmed smaller storage for lupine than for barley (Fig. 7). This would mean that there is very little infiltration in the lupine plots other than to refill the water abstracted by the lupine for evapotranspiration.

These findings indicate that both soil degradation status (soil depth) and disturbance (tillage) are important factors affecting rainfall-runoff relationships in the landscape. In addition to tillage activities, inherent differences in plant root morphology (e.g., length and density) between the barley and lupine could likely be another factor. Most of the root masses of barley are located at shallow depths in the upper part of the soil profile (Lugg et al., 1988) and thereby take water from the top soil, whereas lupine roots grow deeper (Fig. S8 in the Supplement) than barley and extract water from deeper depths (French and Buirchell, 2005). These differences in root water uptake are somewhat visible in slightly greater, albeit not significant, root zone moisture readings (measured from the top $20 \mathrm{~cm}$ ) observed for lupine plots beginning in August 2013 (Fig. S9 in the Supplement).

It is important to note that the fact that lupine did not decrease runoff during this study period does not imply that it would not reduce runoff in the long term. When the roots of lupine decompose, it is likely that biopores and channels would be created (as reported by Meek et al., 1992, and Lesturgez et al., 2004) and that the resulting high vertical and lateral continuity improves the network of macropores (Yunusa and Newton, 2003), which would result in reduced surface runoff and associated erosion.

\section{Conclusion}

We set out to investigate the factors that control runoff initiation by investigating the effects of soil degradation status, landscape position, and different land uses (barley with and without charcoal, and deep-rooted lupine crop) on spatial and temporal rainfall-runoff relationships. We observed and analyzed the discharge of 24 runoff plots installed in groups of three in three transects over a 2-year period. Each group con- 


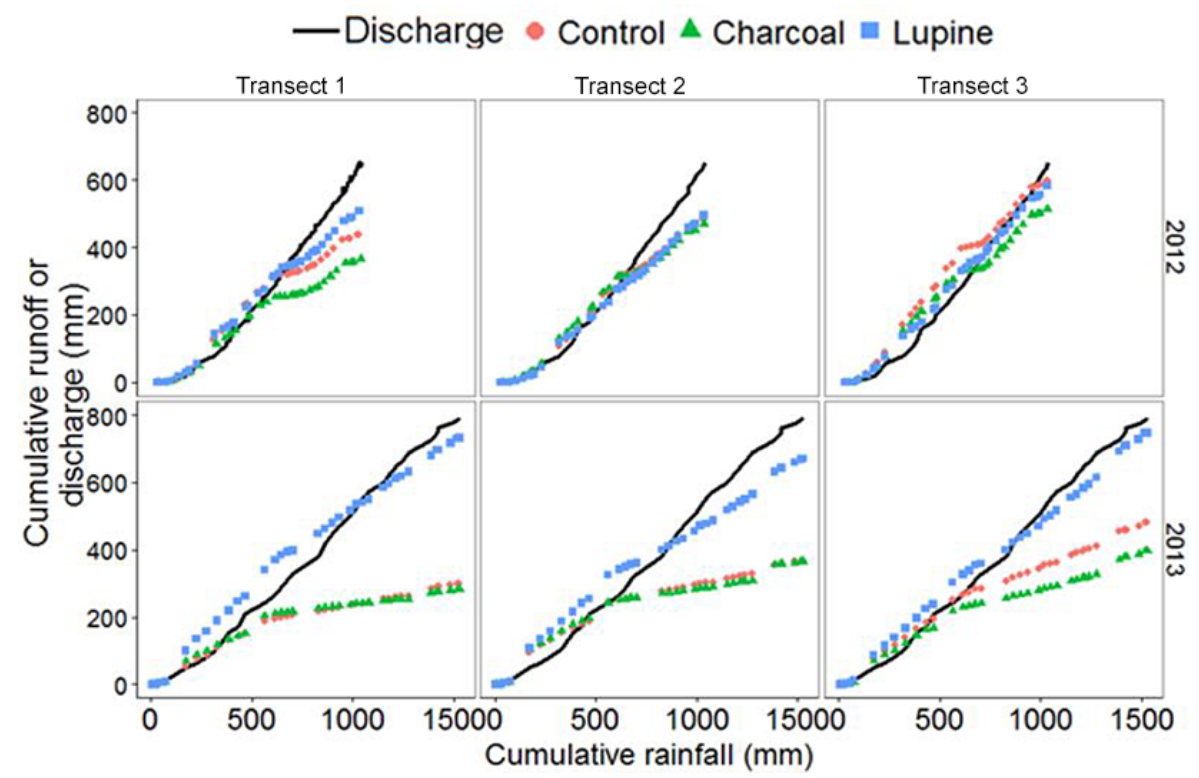

Figure 6. Cumulative rainfall vs. cumulative runoff (from control, charcoal, and lupine plots along three transects) and discharge at the watershed outlet, for 2012 and 2013.

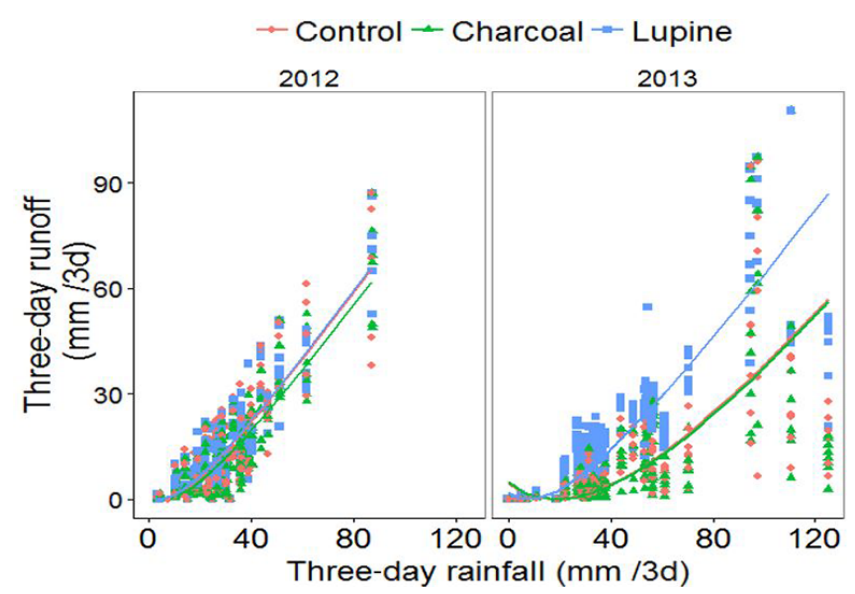

Figure 7. Effect of charcoal amendment and deep-rooted lupine on 3-day soil water storage: 3-day rainfall vs. 3-day runoff with SCSCN fitted lines fitted using the SCS-CN equation (Rallison, 1980). Fitted 3-day storages values in 2012 were 22, 26, and $21 \mathrm{~mm}$ for control, charcoal, and lupine, respectively, and, in 2013, 93, 94, and $40 \mathrm{~mm}$ for control, charcoal, and lupine, respectively.

sisted of plots grown with lupine with no amendment, barley with no amendment, and barley with a charcoal amendment. Monsoonal rains are highly variable even over short distances, and in several cases there was more runoff from the plot than rainfall at the rain gauge. In general, we found that, first, watershed detention storage increased during the first half of the rainy phase, and plot-scale runoff depths exceeded those at watershed scale. The opposite was true later on in the rainy phase due to the occurrence of baseflow at the watershed outlet. Second, under the commonly applied cropping practices (tillage for barley, no tillage for lupine), runoff was greater for lupine than barley. Especially during small rainfall events (approximately $<20 \mathrm{~mm}$ ) in 2013, runoff from non-tilled lupine plots exceeded that of tilled barley plots. Charcoal amendment tended to decrease runoff, but results were not significant. Third, plot-scale rainfall-runoff relationships are greatly affected by root-zone soil water storage capacity, which is directly affected by a range of factors including soil degradation and the amount of water that can percolate to deeper soil layers, tillage practices and fertilization (that were different for lupine and barley treatments), and root morphology of crops (e.g., root length and density).

In the short term, the decreased soil water storage for lupine compared to barley crops in this region implies that lupine has a smaller rainfall threshold for runoff initiation. In the long term, however, lupine may have the potential to actually reduce runoff by improving infiltration rates through the creation of bio-pores once its large taproot decomposes (Fig. S8 in the Supplement). The long-term impact of lupine cropping on runoff processes therefore requires further investigation. Understanding the drivers of hardpan formation and permeability is essential for the development of management approaches that can effectively tackle hardpan occurrence and its hydrologic impacts, in order to ultimately reverse the land degradation trend and reduce erosion.

Our findings are in agreement with other studies that show that rainfall-runoff relationships at a small plot scale are different than at the outlet (e.g., Han et al., 2012; Stoof et al., 2012), and that better use of green water (rainfall) for smallholder agriculture systems in the Ethiopian highlands could 
be achieved by decreasing runoff by increasing the storage of water in the root zone. However, more research has to be done on how best to achieve the latter.

\section{The Supplement related to this article is available online at doi:10.5194/hess-20-875-2016-supplement.}

Acknowledgements. This study was funded by the N. Borlaug Leadership Enhancement in Agriculture Program (LEAP) in cooperation with IWMI's East Africa office, and by a grant from USAID in cooperation with the Higher Education for Development (HED) office by Cornell's Bradfield Award Committee. The authors would like to thank Hans Hurni for his foresight and efforts in establishing the SCRP watershed sites in the 1980s. We also thank Molla Addisu, Debre Markos University, for his help in obtaining some of the materials used in the field. Birhanu Mehiretu (field technician in the Anjeni watershed) was very helpful during the research and field data collection.

Edited by: G. Jewitt

\section{References}

Abel, S., Peters, A., Trinks, S., Schonsky, H., Facklam, M., and Wessolek, G.: Impact of biochar and hydrochar addition on water retention and water repellency of sandy soil, Geoderma, 202203, 183-191. doi:10.1016/j.geoderma.2013.03.003, 2013.

Amsalu, A. and Graaff, J.: Farmers' Views of Soil Erosion Problems and their Conservation Knowledge at Beressa Watershed, Central Highlands of Ethiopia, Agric. Hum. Values, 23, 99-108, doi:10.1007/s10460-005-5872-4, 2006.

Angers, D. A. and Caron, J.: Plant-induced changes in soil structure: Processes and feedbacks, Biogeochemistry, 42, 55-72, 1998.

Asai, H., Samson, B. K., Stephan, H. M., Songyikhangsuthor, K., Homma, K., Kiyono, Y., Inoue, Y., Shiraiwa, T., and Horie, T.: Biochar amendment techniques for upland rice production in Northern Laos: Soil physical properties, leaf SPAD and grain yield, Field Crops Res., 111, 81-84, 2009.

Atkinson, C. J., Fitzgerald, J. D., and Hipps, N. A.: Potential mechanisms for achieving agricultural benefits from biochar application to temperate soils: a review, Plant Soil, 337, 1-18, 2010.

Bayabil, H. K., Tilahun, S. A., Collick, A. S., Yitaferu, B., and Steenhuis, T. S.: Are Runoff Processes Ecologically or Topographically Driven in the (Sub) Humid Ethiopian Highlands? The Case of the Maybar Watershed, Ecohydrology, 3, 457-466, 2010.

Bayabil, H. K., Stoof, C. R., Lehmann, J. C., Yitaferu, B., and Steenhuis, T. S.: Assessing the potential of biochar and charcoal to improve soil hydraulic properties in the humid Ethiopian Highlands: The Anjeni watershed, Geoderma, 243-244, 115123, doi:10.1016/j.geoderma.2014.12.015, 2015.

Bewket, W. and Conway, D.: A note on the temporal and spatial variability of rainfall in the drought-prone Amhara region of Ethiopia, Int. J. Climatol., 27, 1467-1477. doi:10.1002/joc.1481, 2007.
Bewket, W. and Sterk, G.: Dynamics in land cover and its effect on stream flow in the Chemoga watershed, Blue Nile basin, Ethiopia, Hydrol. Process., 19, 445-458, doi:10.1002/hyp.5542, 2005.

Biazin, B., Stroosnijder, L., Temesgen, M., AbdulKedir, A., and Sterk, G.: The effect of long-term Maresha ploughing on soil physical properties in the Central Rift Valley of Ethiopia, Soil Tillage Res., 111, 115-122, doi:10.1016/j.still.2010.09.006, 2011.

Bitew, M. M., Gebremichael, M., Hirpa, F. A., Gebrewubet, Y. M., Seleshi, Y., and Girma, Y.: On the local-scale spatial variability of daily summer rainfall in the humid and complex terrain of the Blue Nile: observational evidence, Hydrol. Process., 3670-3674. doi:10.1002/hyp.7468, 2009.

Chen, H. and Swain, A.: The Grand Ethiopian Renaissance Dam: Evaluating Its Sustainability Standard and Geopolitical Significance, Energy Dev. Front., 3, 11-19, 2014.

Cresswell, H. and Kirkegaard, J.: Soil Amelioration by Plant Roots - the Process adn the Evidence, Aust. J. Soil Res., 33, 221-239, 1995.

Dagnew, D. C., Guzman, C. D., Zegeye, A. D., Tibebu, T. Y., Getaneh, M., Abate, S., Zemale, F. A., Ayana, E. K., Tilahun, S. A., and Steenhuis, T. S.: Impact of conservation practices on runoff and soil loss in the sub-humid Ethiopian Highlands: The Debre Mawi watershed, J. Hydrol. Hydromech., 63, 210-219, doi:10.1515/johh-2015-0021, 2015.

Feoli, E., Gallizia, L., and Woldu, Z.: Processes of Environmental Degradation and Opportunities for Rehabilitation in Adwa, Northern Ethiopia, Landsc. Ecol., 17, 315-325, 2002.

French, R. J. and Buirchell, B. J.: Lupin: the largest grain legume crop in Western Australia, its adaptation and improvement through plant breeding, Aust. J. Agric. Res., 56, 1169, doi:10.1071/AR05088, 2005.

Glaser, B., Lehmann, J., and Zech, W.: Ameliorating physical and chemical properties of highly weathered soils in the tropics with charcoal - a review, Biol. Fertil. Soils, 35, 219-230, doi:10.1007/s00374-002-0466-4, 2002.

Han, S., Xu, D., and Wang, S.: Runoff formation from experimental plot, field, to small catchment scales in agricultural North Huaihe River Plain, China, Hydrol. Earth Syst. Sci., 16, 31153125, doi:10.5194/hess-16-3115-2012, 2012.

Hanson, D. L., Steenhuis, T. S., Walter, M. F., and Boll, J.: Effects of soil degradation and management practices on the surface water dynamics in the Talgua River Watershed in Honduras, Land Degrad. Dev., 15, 367-381, doi:10.1002/ldr.603, 2004.

Herweg, K. and Ludi, E.: The performance of selected soil and water conservation measures - case studies from Ethiopia and Eritrea, Catena, 36, 99-114, 1999.

Hugo, L., Johann, B., Juergen, G., Hiremagalur, G., Mohammad, J., Victor, M., John, M., Martin, O., and Mohamed, S.: Linking Natural Resources, Agriculture and Human Health: Case Studies from East Africa, LEISA Mag., supplement, 17-20, 2002.

Hurni, H.: Principles of Soil Conservation for Cultivated Land. Soil Technol. 1, 101-116, 1988.

Hurni, H., Tato, K., and Zeleke, G.: The Implications of Changes in Population, Land Use, and Land Management for Surface Runoff in the Upper Nile Basin Area of Ethiopia, Mt. Res. Dev., 25, 147154, 2005. 
Kameyama, K., Miyamoto, T., and Shinogi, Y.: Increases in available water content of soils by applying bagasse-charcoals, in: Proceedings of the 19th World Congress of Soil Science: Soil Solutions for a Changing World, Brisbane, Australia, 1-6 August 2010, 105-108, 2010.

Karhu, K., Mattila, T., Bergström, I., and Regina, K.: Biochar addition to agricultural soil increased $\mathrm{CH}_{4}$ uptake and water holding capacity - Results from a short-term pilot field study, Agric. Ecosyst. Environ., 140, 309-313, doi:10.1016/j.agee.2010.12.005, 2011.

Laird, D. A., Fleming, P., Davis, D. D., Horton, R., Wang, B., and Karlen, D. L.: Impact of biochar amendments on the quality of a typical Midwestern agricultural soil, Geoderma, 158, 443-449, doi:10.1016/j.geoderma.2010.05.013, 2010.

Lehmann, J., Gaunt, J., and Rondon, M.: Bio-charhar sequestration in terrestrial ecosystems - a review, Mitig. Adapt. Strat. Global Change, 11, 403-427, doi:10.1007/s11027-005-9006-5, 2006.

Lesturgez, G., Poss, R., Hartmann, C., Bourdon, E., Noble, A., and Ratana-Anupap, S.: Roots of Stylosanthes hamata create macropores in the compact layer of a sandy soil, Plant Soil, 260, 101109, 2004.

Lugg, D. G., Tubaileh, A. S., Kallsen, C. E., and Sammis, T. W.: Irrigation effects on rooting patterns of spring barley, Irrig. Sci., 9, 27-43, 1988 .

McHugh, O. V., Steenhuis, T. S., Berihun, A., and Fernandes, E. C. M.: Performance of in situ rainwater conservation tillage techniques on dry spell mitigation and erosion control in the droughtprone North Wello zone of the Ethiopian highlands, Soil Tillage Res., 97, 19-36, doi:10.1016/j.still.2007.08.002, 2007.

Meek, B. D., Rechel, E. R., Carter, L. M., DeTar, W. R., and Urie, A. L.: Infiltration rate of a sandy loam soil: effects of traffic, tillage, and plant roots, Soil Sci. Soc. Am. J. 56, 908-913, 1992.

Mendoza, G. and Steenhuis, T. S.: Determination of Hydraulic Behavior of Hillsides with a Hillslope Infiltrometer, Soil Sci. Soc. Am. J., 66, 1501-1504, 2002.

Mutema, M., Jewitt, G., Chivenge, P., Kusangaya, S., and Chaplot, V.: Spatial scale impact on daily surface water and sediment fluxes in Thukela river, South Africa, Phys. Chem. Earth, 1-10, doi:10.1016/j.pce.2015.10.001, in press, 2015.

Nyberg, G., Bargués Tobella, A., Kinyangi, J., and Ilstedt, U.: Soil property changes over a $120-\mathrm{yr}$ chronosequence from forest to agriculture in western Kenya, Hydrol. Earth Syst. Sci., 16, 20852094, doi:10.5194/hess-16-2085-2012, 2012.

Nyssen, J., Poesen, J., Haile, M., Moeyersons, J., Deckers, J., and Hurni, H.: Effects of land use and land cover on sheet and rill erosion rates in the Tigray highlands, Ethiopia, Z. Geomorphol., 53, 171-197, doi:10.1127/0372-8854/2009/0053-0171, 2009.

Orchard, C. M., Lorentz, S. A., Jewitt, G. P. W., and Chaplot, V. A. M.: Spatial and temporal variations of overland flow during rainfall events and in relation to catchment conditions, Hydrol. Process., 27, 2325-2338, doi:10.1002/hyp.9217, 2013.

Rallison, R. E.: Origin and Evolution of the SCS Runoff Equation, in: Proceedings of Symposium on Watershed Management, Am. Soc. Civil Eng., Boise, ID, USA, 21-23 July 1980, 912-924, 1980.
R Core Team: R: A language and environment for statistical computing, R Foundation for Statistical Computing, Vienna, Austria, available at: https://www.R-project.org/, last access: 11 January 2015, 2014.

SCRP: Area of Anjeni, Gojam, Ethiopia: long-term monitoring of the agricultural environment 1984-1994, Soil erosion and conservation database, Soil Conservation Research Programme (SCRP), Centre for Development and Environment and the Ministry of Agriculture, Ethiopia, University of Berne, Berne, Switzerland, 89 pp., 2000.

Shougrakpam, S., Sarkar, R., and Dutta, S.: An experimental investigation to characterise soil macroporosity under different land use and land covers of northeast India, J. Earth Syst. Sci., 119, 655-674, 2010.

Steenhuis, T. S., Winchell, M., Rossing, J., Zollweg, J., and Walter, M.: SCS Runoff Equation Revisited For Variable-Source Runoff Areas, J. Irrig. Drain. Eng., 121, 234-238, 1995.

Steenhuis, T. S., Collick, A. S., Easton, Z. M., Leggesse, E. S., Bayabil, H. K., White, E. D., Awulachew, S. B., Adgo, E., and Ahmed, A. A.: Predicting discharge and sediment for the Abay (Blue Nile) with a simple model, Hydrol. Process., 3728-3737, doi:10.1002/hyp.7513, 2009.

Stoof, C. R., Vervoort, R. W., Iwema, J., van den Elsen, E., Ferreira, A. J. D., and Ritsema, C. J.: Hydrological response of a small catchment burned by experimental fire, Hydrol. Earth Syst. Sci., 16, 267-285. doi:10.5194/hess-16-267-2012, 2012.

Taddese, G.: Land Degradation: A Challenge to Ethiopia, Environ. Manage., 27, 815-824, doi:10.1007/s002670010190, 2001.

Tilahun, S. A.: Observations and modeling of erosion from spatially and temporally distributed sources in the (semi) humid Ethiopian highlands, $\mathrm{PhD}$ thesis, Cornell University, Ithaca, New York, available at: http://soilandwater.bee.cornell. edu/publications/Seifu2012PhDthesis.pdf,last access: 6 November 2014, 2012.

Tilahun, S. A., Guzman, C. D., Zegeye, A. D., Engda, T. A., Collick, A. S., Rimmer, A., and Steenhuis, T. S.: An efficient semi-distributed hillslope erosion model for the subhumid Ethiopian Highlands, Hydrol. Earth Syst. Sci., 17, 1051-1063, doi:10.5194/hess-17-1051-2013, 2013.

Tilahun, S. A., Guzman, C. D., Zegeye, A. D., Dagnew, D. C., Collick, A. S., Yitaferu, B., and Steenhuis, T. S.: Distributed discharge and sediment concentration predictions in the sub-humid Ethiopian highlands: the Debre Mawi watershed, Hydrol. Process., 1817-1828, doi:10.1002/hyp.10298, 2014.

van de Giesen, N., Stomph, T.-J., Ajayi, A. E., and Bagayoko, F.: Scale effects in Hortonian surface runoff on agricultural slopes in West Africa: Field data and models, Agric. Ecosyst. Environ., 142, 95-101, doi:10.1016/j.agee.2010.06.006, 2011.

Yunusa, I. A. and Newton, P.: Plants for amelioration of subsoil constraints and hydrological control: the primer-plant concept, Plant. Soil, 257, 261-281, 2003.

Zeleke, G.: Landscape Dynamics and Soil Erosion Process Modeling in the North-Western Ethiopian Highlands, African Studies Series A 16, Geographica Bernensia, Berne, Switzerland, 2000. 